\title{
Study on the Difficulties and Countermeasures of the Construction of Teaching Management Team in Private Colleges and Universities
}

\author{
Chen Li \\ Wuhan Technology and Business University; Wuhan 430065 China
}

\begin{abstract}
Keywords: Private colleges and universities; Teaching management; Team building; Development dilemma; Development countermeasures

Abstract. In recent years, private higher learning institutions are developing rapidly. However, at the same time of rapid development, they have problems in many aspects such as the personnel structure, management team and professional adjustment, which have had adverse impacts on the synchronous improvement of teaching quality and the effect of teaching management. Therefore, the private colleges and universities should strengthen human resource management, creating an conducive environment for the teaching managers' further study, so as to maintain their enterprising spirit, so as to improve the overall quality of the teaching management team. At the same time, teachers should pay special attention to the interactive feet of students, so as to improve the school quality.
\end{abstract}

\section{Introduction}

At present, the scale of education in domestic higher education continues to expand, and private colleges and universities have achieved rapid development. However, there are many problems in the development of private colleges and universities which need to be solved. For example, the teaching quality of private colleges and universities lacks the professional team to manage, and the teaching management team has the development difficulty in the construction. This has a restrictive effect on the improvement of teaching quality [1]. Therefore, private colleges and universities should pay attention to the construction of teaching management team and eliminate the typical problems of teaching management team based on the characteristics of private colleges and universities.

\section{Expression of the Difficulties in the Construction of Teaching Management Team in Private Colleges and Universities}

\subsection{Human resource structure problems}

The human resource structure is the foundation to guarantee the teaching management effect. At present, some private colleges and universities have unreasonable human resource structure in teaching management. The unreasonable human resource structure is mainly reflected in the difference of personnel management ability and the level of personnel age structure. Some private colleges and universities do not pay attention to the problem of teaching management staff. In the long-term development, the problem of human resource structure is very serious. In the teaching management, there is no backbone as a support, so the management effect is limited. Some private colleges and universities do not cultivate their own teaching management team. Most of the teaching management personnel are retired personnel of public universities, and there is a lack of aged and experienced management personnel. The retiree of public school does not combine the practice of private school with teaching management. They adopted the teaching management model of public universities. Due to the differences between public and private universities, the teaching management mode of public universities is difficult to adapt to private universities. In addition, due to the short time of the establishment of some private colleges and universities, there is no corresponding human resource management system for teaching management, which leads to the prominent problem of human resource structure. In addition, some private colleges and universities employ young teaching administrators who lack experience in teaching management, so it is difficult to guarantee the effect of teaching management. [2] 


\subsection{Management team problems}

The management team development of public universities can rely on financial input; in addition, the competent department of education also pays attention to the management of public universities. However, the development of private colleges and universities is mainly funded by students' tuition. While the scale of private colleges and universities expands, the teaching management is difficult to achieve synchronous development. Although the number of students increases, the number of teaching administrators is difficult to increase considering the operation cost. The teaching administrators have the problem of insufficient strength. Many teaching administrators have multiple jobs and it is difficult for them to have all of them. In the event of an emergency, due to the lack of management power, it is difficult to guarantee the handling effect of the incident. Some teaching management personnel of private colleges and universities are in the state of part-time teaching management, which is usually taken by the course management personnel of a certain subject. Under such conditions, the teaching administrators should not only do their own teaching tasks well, but also manage daily affairs. We should not only pay attention to the management of daily events, but also make the management work specific to each student, and learn about students' life and study. Therefore, the daily work of teaching is particularly complex, and managers need to spend a lot of energy managing classes every day. Many managers will feel powerless and exhausted.

\subsection{The continuous adjustment of the major affects the adaptability of the teaching managers}

In order to meet the needs of students to the maximum extent, some colleges and universities often adjust their majors. In addition, as the social demand for talents is also improving, colleges and universities should adjust their majors accordingly, so as to better adapt to the needs of social development and help students find jobs after graduation. [3] However, when the major Settings of colleges and universities are adjusted correspondingly, many new majors will be produced in colleges and universities. As a result of the adjustment of majors, university teaching managers need to learn new knowledge again, which increases the difficulty of working for teaching managers. Especially for the older teaching managers, learning new professional knowledge not only takes a long time, but also feels somewhat powerless due to their age. However, the teaching management personnel of private colleges and universities will affect the effect of teaching management and career under the adverse conditions of constant adjustment of majors.

\subsection{Lack of vocational training system}

In the development of colleges and universities, due to the need of skilled personnel training, professional courses in colleges and universities introduce various new technologies and new techniques. But most of these technologies come from the front lines of production and research. Absorbing "part-time teaching management personnel" from the society cannot guarantee the quality, and the personnel also cannot guarantee the stability. Due to the influence of policy and treatment, many university professional technical teaching managers can only be realized through internal training. However, it is difficult to guarantee the effect of internal training in many private colleges and universities. Due to their lack of supporting vocational evaluation system for teaching administrators, teaching administrators have a poor grasp of new technologies and new techniques. Some private colleges and universities lack the necessary induction training for young teaching managers, and the in-service training for teaching managers will be weakened due to the teaching pressure and economic burden of colleges and universities. Many private universities lack institutional support for teaching assistant training, and only arrange young teaching managers to be engaged in front-line teaching after simple training. In addition, private colleges and universities lack attention on training, and the relative independence of course teaching management personnel and practical teaching management personnel has affected the improvement of professional skills of teaching management personnel. The lack of professional training has affected the further development of many teaching administrators.

\subsection{Institutional deficiencies limit curriculum development}

The improvement of the level of the teaching management personnel needs a supporting system to achieve, and the teaching management personnel need a relaxed growth environment to achieve the 
improvement of the teaching effect. Many private university managers are busy with daily teaching, and have no time to study professional knowledge. It is difficult to achieve breakthroughs in teaching methods, and curriculum development is restricted. The teaching management personnel's teaching lacks the individuality, does not have the teaching characteristic, the teaching is difficult to realize artistry. Subjectively, the teaching administrators in universities lack the awareness of curriculum development, and do not actively develop professional courses. Although many teaching administrators are engaged in a large number of teaching practices, they are short of corresponding teaching results. The lack of achievements of the teaching management has put obstacles in the way of future development. [4]

\subsection{The assessment system of professional title affects the promotion of teaching managers}

For the administrators of private colleges and universities, the promotion of rank is an important part of their career. The promotion of teaching management in private colleges and universities is mainly achieved through the title. The professional title is directly related to the income of teaching administrators in private universities. However, there are many obstacles to the evaluation of the professional title of private university managers. Teaching managers need to have scientific research results, to publish papers, to meet the requirements of professional title evaluation. However, private colleges and universities have a lot of disadvantages in terms of scientific research conditions due to their lower grades. There is a great distance between the scientific research conditions and the application of scientific research subjects and the general undergraduate universities. Therefore, there are many unfavorable conditions for private university managers to carry out academic research and publish scientific research papers. These conditions are an important part of the professional title evaluation of private university teaching managers. The nature of private schools affects the development of teaching administrators in private universities.

\section{How to Improve the Teaching Management of Private Colleges and Universities}

\subsection{Teaching managers should strengthen further education and promotion}

Private colleges management career development dilemma, one important reason is that part of the private colleges teaching management personnel lack of enterprising consciousness, too much content with the status quo, long term can lead to private colleges teaching ability degradation of teaching management, teaching mode, this situation is not conducive to long-term development of teaching management, also affect college students' learning effect. Therefore, various measures should be taken to improve the comprehensive quality of teaching management personnel in private colleges and universities, to create conditions for further study for teaching management personnel, so that they can get more development opportunities, get access to the most advanced technology and the most cutting-edge teaching concepts, so as to facilitate the innovation of teaching mode. Private colleges in conditions allow, can adopt the method of academic exchanges, let more private universities teaching management personnel have access to the advanced education management idea, through the communication can be reference to the advanced teaching mode in colleges and universities, help to realize the original teaching method improvement, remove the influence of the old teaching mode. In addition, the teaching management personnel of private colleges and universities should pay attention to the learning of new knowledge in the professional field, keep the teaching contents fresh, and also help to improve students' awareness of innovation. [5]

\subsection{Teaching administrators should pay attention to the communication with students}

In the current private higher education, students are not cooperating with the teaching management staff. This phenomenon will affect the improvement of teaching effect and cause difficulties in the career development of private higher education management staff. Therefore, in order to realize the career development of private college teaching managers, teachers and students should communicate more. Professional course teaching administrators in universities should listen to students' opinions and encourage them to express their real thoughts. On this basis, the teaching management personnel of private colleges and universities should actively change the existing disadvantages of the original 
teaching mode. In addition, the teaching management personnel of private colleges and universities should be based on the cultivation of students' ability and constantly summarize teaching methods in teaching practice to form teaching topics.

\subsection{Private college teaching managers should keep pace with The Times and be proactive}

Many private universities teaching management personnel daily work more busy, work is trivial, many teaching management personnel are busy preparing and class, every day to finish the homework, do a good job of the student's thought, with class affairs, etc., if the teaching management staff personal goals for lack of, have no sense of enterprising, no positive personal development concept as the direction, will lack the sense of responsibility, in busy all day through the formation of job burnout. Therefore, colleges and universities should have a sense of responsibility. Once they have the responsibility, they will pay attention to their actions and strictly require themselves. Teaching administrators in private colleges and universities should give full play to their professional functions of teaching and solving doubts, increase their sense of social responsibility and personal mission, and constantly explore new methods of teaching and educating people. Due to the current college teaching system, contents, methods and means, etc. Great changes have taken place, the ideological characteristics of college students are constantly changing, so the teaching management of the teaching thought and teaching method should be constantly updated, to keep up with the development of The Times, combining with the development of the situation, promote the reform of teaching, through the theory of education innovation to achieve the integration of knowledge and skills.

\subsection{Create an environment conducive to the development of teaching managers}

In the management, colleges and universities pay attention to creating an environment conducive to education development. They should listen to the opinions and Suggestions of front-line teaching managers through various forms, such as the vocational congress and the exchange meeting, so as to guarantee the democracy and science of school decision-making, and pay attention to safeguarding the legitimate rights and interests of teaching managers. Humanized management should be applied to the teaching management personnel, and the conditions should be created for the career development of the teaching management personnel. Schools in the long development of members of teaching management as the core, pay attention to play to the teaching management staff of professional expertise, efforts to create a conducive to the development of teaching management space, make the teaching management staff can feel the humanistic care in the harmonious atmosphere, can have more time to complete the teaching mission, improve the teaching effect. [6]

\subsection{The school should pay attention to human resource management}

With the rapid development of society and the transformation of society, private colleges and universities should attach great importance to the management of human resources to maintain their advantages in competition. In view of the disadvantages of the development of education in universities, reform and innovation are carried out boldly. Human resource management should be an important part of the management of colleges and universities. In the face of market competition, colleges and universities should change their original management mode and make innovations in human resource management. The university should regard the manpower of the university as the motive power of development. Human resource management should be innovative, which is also a necessary choice for the development of The Times. It is necessary to change the human resource management mode, which is not conducive to the development of private college teaching managers, and create conditions for the development of excellent talents. Only with talents as a guarantee, can colleges and universities have competitive advantages. In addition, by innovating the human resource management system, more training opportunities should be provided for the teaching management personnel, which can effectively improve the management level of the teaching management personnel, stabilize the teaching management personnel team of private colleges and universities, increase the responsibility of the teaching management personnel, and inspire the enthusiasm of the teaching management personnel of private colleges and universities. 


\section{Conclusion}

The teaching management team is the foundation to guarantee the teaching quality. Due to the influences of various reasons, the construction of teaching management team is lagging behind, which affects the improvement of education quality. In order to realize the sustainable development of private colleges and universities, private colleges and universities should take corresponding measures and reform measures to realize the modernization of teaching management and improve the overall level of teaching management.

\section{Reference}

[1] Zhao Ying. Preliminary exploration on the construction strategy of teaching management team in private universities-taking Jilin province as an example [J]. Journal of Changchun University, 2014, 24(8):1120-1123.

[2] Xu Caiyun, Wang Wei, Wang Jie. Research on the status quo and countermeasures of the teaching management team in private universities [J]. Journal of Hubei Institute of Technology, 2016, 36(2):41-42.

[3] Wu Jianjun, Yuan Zhizhong. An analysis of the construction of grassroots teaching management team in private colleges and universities-a case study of Chongqing university of humanities and technology (formerly the Yucai college of southwest university) [J]. Chongqing and the World: academic edition, 2014, 31(1):55-58.

[4] Zhang Xiaolin. A brief analysis of the construction of teaching management team in private universities [J]. Value Engineering, 2015, 52 (10):293-294.

[5] Li Jihui. Thoughts on innovation and practice of teaching management in private colleges [J]. Journal of Shandong Agricultural Engineering College, 2014, 31(2):189-190.

[6] Pang Zhaojun. An analysis of the impact of training of teaching staff in private universities on the construction of teaching management team [J]. Operation Management, 2015, 76(18). 